\title{
What Remains to Be Discovered?
}

\author{
Co pozostaje do odkrycia?
}

\author{
Pavel Nováček \\ Department of Development and Environmental Studies, Palacký University Olomouc, Czechia \\ ORCID https://orcid.org/0000-0003-3903-4948• pavel.novacek@upol.cz \\ Received: 05 June, 2021; Revised: 18 Sep, 2021; Accepted: 29 Sep, 2021
}

\begin{abstract}
What major scientific breakthroughs will occur in the rest of the 21st century? We can hardly imagine what discoveries await us in the fields of physics, biology, human health, or artificial intelligence. Every time people think that everything has already been discovered, there occurs another breakthrough. However, it is impossible to predict specifically when and what it will be. Among the most promising challenges on the border between science and our imaginations, is an exploration of our universe, and potential contact with an extra-terrestrial civilisation, better understanding of space, time, matter, and energy (including "dark matter" and "dark energy") and, of course, the "unthinkable" potential of the human brain. It seems that what may never be discovered is scientific evidence of life after death. This is not found on the border between science and our fantasy (imagination), but on the border between science and faith.
\end{abstract}

Keywords: limits of knowledge, scientific discoveries, breakthroughs in science, science, faith

Streszczenie: Jakie główne przełomy naukowe nastąpią w pozostałej części XXI wieku? Trudno sobie wyobrazić, jakie odkrycia nas czekają w dziedzinie fizyki, biologii, zdrowia ludzkiego czy sztucznej inteligencji. Za każdym razem, gdy ludzie myśleli, że wszystko zostało już odkryte, następował kolejny przełom. Jednak nie można dokładnie przewidzieć, kiedy nastąpi kolejny przełom i czego będzie dotyczył. Do najbardziej obiecujących wyzwań na pograniczu nauki i naszej wyobraźni należy eksploracja wszechświata i potencjalny kontakt z pozaziemską cywilizacją, lepsze zrozumienie przestrzeni, czasu, materii i energii ( $w$ tym "ciemnej materii" i "ciemnej energii") oraz niezbadany potencjał ludzkiego mózgu. Wydaje się, że to, co być może nigdy nie zostanie odkryte, to naukowe dowody życia po śmierci, ponieważ dotyczą one obszaru, który nie leży na granicy nauki i naszej fantazji (wyobraźni), ale na granicy między nauką a wiarą.

Słowa kluczowe: granice poznania, odkrycia naukowe, przełomy w nauce, nauka, wiara 


\section{Introduction}

It is mysterious and challenging issues that lead the human spirit to new and bold breakthroughs. After going down so many dead ends and blind alleys at times, a discovery or invention appears that changes our perceptions of the world and opens up new, previously unthinkable possibilities. The beautiful thing about scientific research is, among other things, that even the exploring of paths leading nowhere, makes some sense. No one is alone, and the previous failures of honest researchers bring, sooner or later, a new discovery, new knowledge, and with it, new hope. Sir John Maddox was editor-in-chief of the journal, Nature. Then, in 1998, he published a book with the telling title: What Remains to be Discovered. In the book, he wonders what major scientific discoveries will occur in the $21^{\text {st }}$ century in the fields of physics, human health, and intelligence, and also, in the field of the prevention of natural, as well as man-made disasters.

In 1900 , nobody knew the simple Einstein equation $\mathrm{E}=\mathrm{mc}^{2}$, but less than half a century later, the atomic bomb developed thanks to this equation, changed the world forever. ${ }^{1}$ At the beginning of the $2 \mathrm{O}^{\text {th }}$ century, biologists did not know how heredity worked, but in 1957, Francis Crick and James Watson discovered the structure of DNA (the carrier of genetic information), which has the shape of a double helix, and showed how evolution moves forward through genes.

John Maddox claims that the $21^{\text {st }}$ century will bring discoveries we can hardly imagine in the fields of physics, biology, and in other disciplines. These discoveries will confront us with crucial and difficult questions, without any obvious answer, as to what is wrong and what is right.

We will almost certainly be able to clone, not just a sheep (which has already happened), but also human beings. This raises

$1 \mathrm{E}=\mathrm{mc}^{2}$ energy equals mass times the velocity of light squared. a wide range of difficult ethical, but also legal questions. We will be able to influence the weather, and perhaps even the climate. However, with the awareness of the imperfections and inconsistencies of human nature, would we like to live in such a world? Maybe, we will embrace immortality in the $21^{\text {st }}$ century, but is this not the temptation that hides one of the greatest threats to humanity? Be that as it may, one thing is beyond doubt. Human curiosity is like an unquenchable thirst, and the human spirit must create to give life some meaning.

\section{Scientific breakthroughs - past and future}

According to Josef Svoboda (Svoboda and Nováček 2002), since the times of Galileo and Copernicus, who literally shook the conceptual foundations of cosmology, there have been three of the most important discoveries:

\section{Principles of evolution formulated by Lamarck and Darwin}

There has been the evolution of organisms from their very beginning, almost four billion years ago, up to humans. There is also a common basis of life, located in the cells that unite into a mutually beneficial structure. They then act independently, but in a co-ordinated way, as a new form of life at a higher level. The process of evolution is continuous. The idea of evolution shook the consciousness of the educated world, including the Church, in a similar manner, as did Copernicus's idea that the Earth is not the centre of the universe.

\section{Principle of heredity formulated by Mendel}

Biological inheritance is an extremely conservative mechanism, which almost contradicts the theory of evolution. Without this, the changes in living organisms would come so quickly, that actually nothing would remain stable. However, changes in species are very gradual, and thus, resistant to sudden changes. 
Theory of relativity formulated by Einstein

Einstein's theory was a breakthrough in rational knowledge. Time and space are variable, the only invariable and abstract constant (questioned by some physicians, nowadays) is the speed of light. Any increase in the speed of any material particle, results in an increase in its energy and mass. If such a particle reached the speed of light, it would reach the mass of the universe.

What breakthrough discoveries await us in the $21^{\text {st }}$ century, and how will they affect our porceptions of the world?

In history, every time people began to think that everything had already been discovered, another discovery or breakthrough duly occurred. Nevertheless, we have learnt that it is impossible to predict, specifically, when and what it will be. When the first man landed on the Moon fifty-two years ago, most experts would have agreed that the year, 20oo, would see a spaceship with a human crew on Mars. Instead, we think, nowadays, that sometime around 2030, we could perhaps go back to the Moon. On the other hand, a half century ago, who would have predicted the massive use of desktop computers, the Internet, web networks, and cell phones?

If we want to try, at least approximately, to map out the areas of human knowledge, which could bring some important and breakthrough discoveries in the future, we must clarify what we mean by science, or more precisely, what do we consider to be a serious and legitimate subject for our research?

The famous physicist, Ernest Rutherford believed, at the turn of the $20^{\text {th }}$ century, that the only thing worth caring about was physics. In modern times, there is nobody to dispute other exact disciplines, such as chemistry and biology. Jared Diamond is right to point out in his book, Collapse, that we must understand science in a broader sense, not just as an investigation of something we can measure and weigh (which is, among exact scientists, still a widely-held opinion): "Science is often poorly defined as a 'summary of knowledge', attained through repeated, controlled experiments in laboratories. In fact, science is something much broader: the acquisition of reliable knowledge about the world." (Diamond 2005).

Let us have a look, without any claim to completeness, at the areas which might prove to be a breakthrough. Nevertheless, we must dare to go beyond "repeated, controlled experiments" to the border between science and our imagination (fantasy), perhaps even to the border between science and fiction.

\section{Going into space}

Americans want to launch around 2030 (after six decades!), a manned spacecraft to the Moon. Later, when a permanent lunar station is in operation, astronauts will be exchanged every six months. Then, a manned flight to Mars should follow (no one dares to set a date for that flight). Such a trip would, today, cost an estimated USD 500 billion $^{2}$ and the crew could die, as their DNA would be damaged by solar radiation, from which, they could not be entirely shielded during a long mission (Bryson 2003).

What would the colonisation of Mars look like? For example, if we destroyed the environment here on Earth, how could Mars be developed as a replacement?

If we did not find any life on Mars, it would be possible to transfer it there from Earth in two steps. The first step would be to heat up its atmosphere enough, so that a thick layer of carbon dioxide is formed. To do so, gases (chloro-hydrocarbons) causing the greenhouse effect could be used, or the polar caps of Mars could be covered with foils, which absorb heat. This would cause the ice to melt and the restoration of running water on Mars. This process, however, would take at least one hundred years.

The second step is to create air, but the transformation of an atmosphere with

2 It is a large sum of money, on the other hand, it is only less than a third of annual global military expenditure. Even the United States alone, spends more money on armaments, each year. 
carbon dioxide to a life-giving atmosphere would take tens of thousands of years. The imported bacteria and plants would consume carbon dioxide and produce oxygen. Gradually, with the increasing level of oxygen, various species of plants and animals could be introduced to the planet.

James Lovelock (1979), author of the Gaia hypothesis, worked for NASA on a project dealing with the possibilities of life on Mars. The scientist knows what he is talking about when he claims that, in the foreseeable future, the colonisation of Mars and other objects in space, is out of the question. We will have to make do with Earth.

Let us pose another important question, which has interested people since ancient times. Is there life elsewhere in the universe? If so, is it an advanced form of life? Is it at least remotely similar to our way of life (based on compounds of carbon)?

If, one day, we established contact with extra-terrestrial civilisations, would they be friendly or hostile to us? Will we be able to communicate with them if they are significantly more advanced? Will we be able to learn from them? Will they be willing to teach us? Would they believe in one God?

We could formulate dozens of questions, and the answers to each of them, would be crucial for the further development of human civilisation.

For decades, the most powerful receivers have been trying to capture signals from space, which would indicate extra-terrestrial intelligence, but so far unsuccessfully. ${ }^{3}$ In 1961, the radio astronomer, Frank Donald Drake, presented a mathematical equation to estimate the number of civilisations that might exist in our galaxy, and would currently be able to make contact with other civilisations. It states that:

$$
N=R^{*} \times f_{p} \times n_{e} \times f_{l} \times f_{i} \times f_{c} \times L
$$

3 The best-known project is: Search for Extra-Terrestrial Intelligence (SETI), which deals with searching for extra-terrestrial civilisations by the interception of radio communication. The project has been running since 1960, and its initiator was Frank Drake.
$\mathbf{N}=$ the number of civilisations in our galaxy, which would be able to make contact with other civilisations

$\mathbf{R}^{*}=$ the rate of formation of stars at the time of the Solar System's formation (one per year as estimated at that time)

$\mathbf{f}_{\mathrm{p}}=$ the fraction of those stars with planets (o.2 as estimated at that time)

$\mathbf{n}_{\mathbf{e}}=$ the number of planets in one solar system that can potentially support life $(1-$ 15 by estimation, which is too optimistic from today's perspective)

$\mathbf{f}_{\mathbf{l}}=$ the fraction of those planets that actually go on to develop life at some point (estimated by Drake as 1)

$f_{i}=$ the fraction of those planets that actually go on to develop intelligent life (estimated $10^{-7}-1$ )

$\mathbf{f}_{c}=$ the fraction of civilisations that are developed enough to use a technology that releases detectable signals of their existence into space ( $0.1-0.2$ by estimation)

$\mathbf{L}=$ the lifetime of such civilisations (this estimate is entirely speculative, as it could be between thousands of years and one hundred million years).

According to this equation, with the estimated values and with the estimated number of 150 billion suns in our galaxy (the Milky Way), there could be from twenty to 60 million advanced civilisations at the present time. It is important to realise that Drake's equation does not say whether there are, or are not, advanced civilisations, but it states it is quite reasonable to assume that such civilizations exist. Therefore, it seems that in the near future, we will not become bored revealing the mystery of the universe. Today, sixty years after the publication of the Drake equation, we are more cautious about the existence of intelligent life in space, perhaps even more sceptical. Maybe there are millions of advanced civilisations in the universe, but it is also possible that we are alone in our galaxy, and perhaps even in the whole universe. This is a good reason to consider life and civilisation on this planet as a great gift and miracle. 


\section{Mass, energy, space, and time}

We live in a material world, but since the time of Einstein, we have realised that matter is far from being only what it seems. In Einstein's theory of relativity, space is not three-dimensional, and time is not one-dimensional. Space and time are not separate but create spacetime. If we travelled at the speed of light, time would come to a complete stop and distances would disappear. Based on present knowledge, a material object can, thus, never reach the speed of light. If any material object reached the speed of light, its mass would become infinite. However, an infinitely material body would require an infinite amount of energy, in order to move. That is why physicists claim that nothing can reach the speed of light, with one exception: light travels at the speed of light, because it is not a material object. It has zero mass. Albert Einstein, allegedly, once declared that he wanted to spend the rest of his life investigating the essence of light.

Studying the essence of matter is not a simple or a cheap business at all. From today's perspective, nuclear fission is relatively easy, but splitting an atom nucleus requires a lot of electric power and money. The United States planned to build a supercollider capable of investigating "the ultimate nature of matter". The tunnel, in which the particles would be accelerated, would measure 84 kilometres, and could attain extremely high energies. It would cost US $\$ 400$ billion, with additional hundreds of millions of dollars per year for its operation. Therefore, Congress rejected its construction (Bryson 2003). However, we have reason to believe that visible matter in the Universe, is not at all the only thing existing there. If cosmological theories are correct, planets, stars, galaxies, and galaxy clusters, probably represent about only $5 \%$ of all the matter in the Universe. Another $30 \%$ is formed by invisible "dark matter". The rest is, in all likelihood, "dark energy", a force that, as astronomers believe, keeps the Universe expanding increasingly, instead of shrinking by gravity, into a great cosmic collapse.

That is not very encouraging, but on the other hand, the advances in understanding the nature of matter, energy, time, and space, over the past hundred years are fascinating. Who knows what physics will be like in another hundred years? It may be, as Josef Svoboda (2006) claims, more accurate and more precise in describing phenomena, but less and less clear in viewing the fundamental essence that forms physical existence.

Stephen Hawking (1988) also warns us against overlooking what is most fundamental in our search: "Up to now, most scientists have been too occupied with the development of new theories to ask the question, why. ... Philosophers have not been able to keep up with the advance of scientific theories. ... However, if we do discover a complete theory, it should in time be understandable, in broad principle, to everyone, and we shall be able to take part in the discussion of the question of why it is that we and the Universe exist."

\section{Potential of the brain, fusion of the brain and computer}

In 1999, Ray Kurzweil published a book, titled: The Age of Spiritual Machines, addressing the possible emergence of artificial intelligence that would surpass the human one in all aspects. "It is said that people over-estimate what can be accomplished in the short term and under-estimate the changes that will occur in the long term, says Kurzweil.

In 1999, the most powerful computers were about one million times simpler (less efficient) than the human brain. In the longterm perspective, the number of operations the computer is able to process doubles every 12 months. Thanks to this trend, standard computers acquired a memory and processing speed comparable to that of the human brain in 2020 .

The human brain has approximately 100 billion neurons. Each of them has about 1,000 connections with the neighbouring 
neurons. Thus, there are roughly 100 trillion $\left(100 \times 10^{12}\right)$ connections in the brain. Each connection is capable of 200 calculations per second. The brain can, therefore, simultaneously perform up to 20 million billion calculations per second. ${ }^{4}$

In 1997, a computer worth US \$2,0oo was capable of two billion calculations per second. As the capacity doubles every year, by 2020 , computers reached a capacity of 20 million billion calculations per second, which is equal to the capacity of the human brain.

The memory capacity of the brain equals approximately a million billion bits. In 1998, the computer memory (RAM) of a billion bits, cost approximately US \$ 200. The memory capacity doubles, on average, every 18 months. It means that in 2023 , there will be a memory of a million billion bits available for about US \$ 1,ooo.

It is, therefore, rational to anticipate that a personal computer will match the speed and capacity of the human brain very soon. If the development continued at the same pace until 2030, a personal computer would have a capacity and processing speed equalling the brains of several hundred people. In 2048 , it would equal the brains of all the USA's inhabitants, and in 2060, it would equal 1,ooo billion human brains. Another giant leap would take place, if we managed to design quantum computers, which would use the qualities of sub-atomic particles to process information.

"Technology is the continuation of evolution by other means, and is itself, an evolutionary process" says Kurzweil. He concludes that the next evolutionary stage will comprise a fusion of humankind with technology, and evolution will continue to proceed in an exponential fashion.

Ray Kurzweil suggests that our only chance is a symbiosis of humans with technology. On the other hand, Nick Bostrom

4. The human brain also demands a lot of energy. While its mass forms a mere $2 \%$ of the body's mass, it consumes $20 \%$ of its energy. and Anders Sandberg (2017), for example, are not so optimistic. According to them, the challenge we face in trying to enhance human beings is so difficult, as to be hopelessly beyond our reach, at least until the biological sciences and the general level of human abilities have advanced, vastly beyond our present state. They are much less optimistic than Kurzweil, stating: "Evolution is a process powerful enough to have led to the development of systems - such as human brains - that are far more complex and capable than anything that human scientists or engineers have managed to design. It would be foolish to suppose that we are, currently, likely to be able to do better than evolution."

Manfred Spitzer (2012) draws attention to numerous risks and speaks directly about the dangers of digital dementia. He claims that digital media deprive us of the need to perform mental work. Additionally, digital media forms are addictive, especially if they are accessible to young children. According to Spitzer, digital media can damage the body and mind in the longrun (whereby we do not move, and we are "hunched" in front of the computer screen for many hours, day after day). Nervous connections wither away, and the new ones do not survive, because they are not needed.

The ability to learn is dramatically decreasing in children and adolescents; there are attention and reading disorders, sleeping disorders, dullness and anxiety, depression, weight gain (from overweight to obesity), violent tendencies, and the resulting general decline of society.

There is a substantial problem with Kurzweil's vision, and that is the origin of consciousness. It is still a mystery to us how consciousness develops. Is it a logical outcome of highly organised matter, or is it independent of matter? Until now, we have not been able to explain where our mind originated from, or how it works. 


\section{Conclusion}

A fusion of people with computers is possible and perhaps useful, but how far should it go? We are about to search for the answers to questions that are not easy at all, and there is probably no unambiguous answer to what is right, and what is wrong. Now, we can only speculate which path future evolution will take. Whether the biological, as it has been so far, or one combining biology and technology, or whether we become mere information beings in our essence.

The technological possibilities may trigger an evolutionary "split" of the Homo sapiens species. Symbiosis of the human brain and the immensely powerful computer could create a "superhuman", who would be capable of processing all the information in the world, within a split second, and of the instant and rational evaluation of all the options, when making a decision. This type of human being would sooner or later become "immortal" (if we became information beings) or would live for a very long time, because it could technologically repair and improve its biological body, almost to infinity.

Not everyone would be attracted by this vision of the human future. Some people would probably prefer to remain on the "primitive", biological level, even if their possibilities and skills were much more limited, and they would die at the age of 80 to 120 . Their decision would be based on the faith that life does not end with earthly death, and that one's consciousness (personality) will not cease to exist. Quite the opposite, if we are but pilgrims and temporary guests on Earth, we have some hope that our story will continue in another dimension and quality.

If a child decides before it is born, it might not want to come out of the safe mother's womb, through the dark tunnel, into the uncertainty of an unknown world. However, if it did not set out on this journey into the unknown, it would kill its mother and itself, too. Similarly, it is our lot and responsibility, to resolve at the right time, starting another journey into the unknown - a step beyond the threshold of death with hope, like generations of our ancestors did.

Raymond A. Moody, a psychologist and physician, has studied the experiences of clinically dead people, for many years. His most famous book is Life after Life (1975). Based on the experience of several hundred people, who experienced clinical death, Moody compiled a list of nine experiences common during clinical death (not everyone actually had all the nine experiences): hearing strange sounds (resembling buzzing); a feeling of inner peace and the absence of pain; floating outside one's own body; a feeling of travelling through a tunnel; a feeling of rising into heaven; seeing others, usually close friends and relatives (the deceased); meeting a spiritual (luminous) being; "reviewing" one's life; a feeling of reluctance to return to life.

The above experiences are nowhere near scientific evidence of life after death (a fact emphasised by Moody himself). Yet, interestingly enough, all the people who have undergone these states of altered consciousness, insisted that thanks to this experience, they found a much better balance, and ceased to fear death. At the same time, they stated they realised what an enormous gift life was, and resolved to fulfill the rest of it, as fully as possible. Here is, perhaps, the border between "what remains to be discovered" and what will never be discovered on this Earth, as this is the border between science and faith.

Funding: This research received no external funding. Institutional Review Board Statement: Not applicable.

Conflicts of Interest: The author declares no conflict of interest.

\section{References}

Bryson, Bill. 2003. A Short History of Nearly Everything. New York: Broadway Books.

Bostrom, Nick, and Anders Sandberg. 2017. "The Wisdom of Nature: An Evolutionary Heuristic for Human Enhancement." In Philosophical Issues 
in Pharmaceutics, Philosophy and Medicine, vol. 122, edited by Dien Ho, 189-220. New York: Springer.

Diamond, Jared. 2005. Collapse: How Societies Choose to Fail or Succeed. New York: Viking Books.

Hawking, Stephen. 1988. A Brief History of Time: From the Big Bang to Black Holes. New York: Bantam Books.

Kurzweil, Ray. 1999. The Age of Spiritual Machines. New York: Penguin Books.

Lovelock, James. 1979. Gaia: A New Look at Life on Earth. Oxford: Oxford University Press.

Maddox, John. 1998. What Remains to be Discovered. Mapping the Secrets of the Universe, the Origin of Life, and the Future of the Human Race. New York: The Free Press.
Moody, Raymond. 1975. Life after Life. Tracy: Mockingbird Books.

Spitzer, Manfred. 2012. Digitale Demenz: Wie wir uns und undere Kinder um den Verstand bringen. München: Droemer Knaur.

Svoboda, Josef, and Pavel Nováček. 2002. Rozhovory od Bakerova jezera. Na hranici reality, metareality a fikce. [Interviews from Baker Lake. On the border of reality, metareality and fiction]. Luhačovice: Atelier IM.

Svoboda, Josef. 2006. "Life as an Unfolding Biocosmos." In Life as We Know It, edited by Joseph Seckbach, 431-444. New York: Springer. 